Article

\title{
Exploring Ethos in Contemporary Ghana
}

\author{
Gladys Nyarko Ansah *(i) and Augustina Edem Dzregah \\ Department of English, University of Ghana, Accra, Ghana; ADzregah@ug.edu.gh \\ * Correspondence: gansah@ug.edu.gh
}

Received: 22 June 2020; Accepted: 10 July 2020; Published: 15 July 2020

check for updates

\begin{abstract}
In this article, we discuss contemporary Ghanaian ethos reflecting on female sexual behavior as a discursive construction that shifts and changes across time and space. Borrowing from Nedra Reynold's concept of ethos as a location, we examine the various social and discourse spaces of different rhetors on female sexual behavior in Ghana and how each establishes ethos through identity formations and language use from various positions of authority. With multiethnic, multilingual, and multiple religious perspectives within the Ghanaian population, how does ethos and moral authority speak persuasively on female sexual behavior? We examine contemporary discourses governing normative female sexual behavior and presentation as revealed in both proverbs and social media to drive the discussion toward how these discourses of female sexual behavior and ethos are discursively constructed in contemporary Ghanaian society.
\end{abstract}

Keywords: contemporary ethos; Ghana; dialogic; heteroglossia; postmodern discourses; proverbs; sexual identity; sexual presentation; conservative values; tradition

\section{Introduction}

In Book 3 of his Rhetoric, Aristotle discusses proverbs (Gr. paroimiai) under the heading of lexis or style (3.11.14); that is, as figures of speech that contribute to the speaker's projection of a favorable self-image. Discussing Aristotle, George A. Kennedy (1991) describes proverbs as "witnesses," in which the testimony they provide comes from the community, not from an individual (p. 108). They represent, as it were, the collective "voice" of conservative culture. In addition, "some proverbs," Aristotle notes, "are also maxims" (2.21.10), in that they contribute directly to persuasion. By Aristotle's own authority, we turn to Book 2 of the Rhetoric and its discussion of maxims (Gr. gnōmōi) as structures, not just of style, but of argument"

"In regard to the use of maxims, it will most readily be evident on what subjects, and on what occasions, and by whom it is appropriate that maxims should be employed in speeches ... . Now, a maxim is a statement, not however concerning particulars, as, for instance, what sort of a man Iphicrates was, but general; it does not even deal with all general things, ... but with the objects of human actions, and with what should be chosen or avoided with reference to them. And as the enthymeme $^{1}$ is, we may say, the syllogism dealing with such things, maxims are the premises or conclusions of enthymemes without the syllogism. For example: "No man who is sensible ought to have his children taught to be excessively clever," is a maxim; but when the why and the wherefore are added, the whole makes an enthymeme; for instance, "for, not to speak of the charge of idleness brought against them, they earn jealous hostility from the citizens." (2.21.2-5)

1 In Aristotelian thinking, an enthymeme is a short (incomplete) argument that involves contradictions (Rapp and Zalta 2010) because one of its premises for achieving syllogism (a three-part argument with two premises and a conclusion) is assumed rather than clearly stated. 
Proverbs and maxims, thus, are invitations to an audience's assent. Strictly speaking, a maxim does not need to be explained (in effect, to be built into an enthymeme). Rather, a maxim persuades because it claims common sense wisdom as "already known" or "generally agreed" (2.21.5).

By building proverbs into his speech, the rhetor taps into the common sentiments of a community, thereby gaining "cultural authority" (a vital component of ethos). More than lexis and even, perhaps, more than logos, the gnomic utterances of proverbs and maxims contribute to a speaker's ethos. Yet not every speaker can employ proverbs or maxims decorously and effectively, as Aristotle suggests:

The use of maxims is suitable for one who is advanced in years, and in regard to things in which one has experience; since the use of maxims before such an age is unseemly, as also is story-telling; and to speak about things of which one has no experience shows foolishness and lack of education. A sufficient proof of this is that rustics especially are fond of coining maxims and ready to make display of them. (2.21.9)

Let us summarize this discussion: According to Aristotle, a proverb is a gnomic or sententious statement derived from tradition and most suited to be spoken by men (and we would add, women) of a particular age and socioeconomic status.

The above definition applies to speakers in ancient Greece. To what extent does it apply to contemporary Ghana? The specific focus of this essay - the use of proverbs in the Ghanaian languages of Akan and Ewe-recapitulates much of the description above. In Ghanaian society, the proverb expresses the "collective 'voice'" of traditional (hence, conservative) culture. Traditionally, these are "handed down" quite literally from one generation to the next. Though women as well as men deploy them, the proverbs under analysis here seek to set norms and bounds upon women's (sexual) morality and behaviors.

Ghana today finds itself in transit ethically and ethotically, in that the traditional proverbs (and the conservative sexual morality they undergird) are pressured by different and more modern texts and voices. The proverbs mouthed and taught by parents and grandparents are coming into collision with new voices-a generation of women who counter the older sexist norms that allow men with money and power to exploit women -all the while blaming the women for sexual immorality. The masculinist "double standard" preached in these traditional proverbs is being tested and questioned by young Ghanaian women today, who have access to the technologies of social media. These new media platforms-Twitter in particular-allow women to "construct an ethos" that counters conventional or conservative morality. Yet this same media is cohabited by multiple voices representing the spectrum of Ghanaian society of old and young, male and female, rich and struggling. Within this media, the old proverbs continue to wield their normative control of Ghanaian attitudes towards woman's roles and behaviors. It is for this reason that we declare Ghanaian society to be "in transit," ethically and ethotically.

Before proceeding to an analysis of Ghanaian proverbs, we need a working definition of ethos. Let us begin, then, by noting a rift in current scholarship: In the classical Aristotelian model, two versions have arisen. The first (and most commonly cited) version holds that persuasion "through character ... should result from the speech" and "not from a previous opinion that the speaker is a certain kind of person" (Rhetoric 1356a as cited in Baumlin and Meyer 2018). The second derives from this Special Issue on Ethos: James S. Baumlin and Craig A. Meyer explain: "If trust comes 'from the speech' solely, then the speaker's ethos is fashioned from within discourse and becomes part of the discourse in its totality." Aristotle elaborates:

But since rhetoric is concerned with making a judgment ... it is necessary not only to look to the argument, that it may be demonstrative and persuasive but also [for the speaker] to construct a view of himself as a certain kind of person and to prepare the judge; for it makes much difference in regard to persuasion... that the speaker seem to be a certain kind of person and that his hearers suppose him to be a certain kind of person and that his hearers suppose him to be disposed in a certain way. (Rhetoric 1377b as cited in Baumlin and Meyer 2018) 
Within this rhetorical model, Aristotle illustrates a speaker "construct[s] a view of" themselves, a verbal performance occurring within the speech. However, a socially-constructed model of ethos privileges culture over self and, thereby, reduces the self to behaviors in the context of the culturally accepted norms, proverbs, and participation in the traditions of the culture. Karen Burke LeFevre (1987) notes "Aristotle's Rhetoric presupposes a social context" (LeFevre 1987, Invention, p. 45). She continues:

Perhaps most pertinent to a social perspective is Aristotle's concept of ethos ... [which] arises from the relationship between the individual and the community. "Ethos," says Karlyn Kohrs Campbell, "does not refer to your peculiarities as an individual but to the ways in which you reflect the characteristics and qualities that are valued by your culture or group. In Aristotle's view, ethos cannot exist in isolation; by definition it requires possible or actual others ... . [I]n fact, the Greek meaning for "ethos" as "a habitual gathering place" calls forth an image of people coming together ... . Ethos, we might say, appears in that socially created space, in the "between," the point of intersection between speaker or writer and listener or reader." (LeFevre 1987, Invention, pp. 45-46)

In contemporary Ghana, we see the latter version of ethos at play, though we look to the possibility that Ghanaian women can, in time, construct themselves in liberatory ways.

The contemporary Ghanaian woman wears her inherited ethos proudly; this ethos, this "cultural dress," is woven from multiple texts whose components include the traditional proverbs governing sexual norms and behaviors and their own movement toward creating a contemporary ethos of themselves. In this essay, we explore the ways that social media has added a "new voice" to the polyphony of Ghanaian popular discourse and the range of responses that this "new voice" has generated.

\section{A New Voice in a Traditional Environment}

Priscilla Opoku-Kwarteng, more commonly known as Ebony Reigns, was born on 16 February 1997. The self-proclaimed 1990s bad gyal ${ }^{2}$ dropped out of secondary school to take up a music career, releasing her first hit single song in December 2015. Both her personality and music brand were perceived by many Ghanaians as openly violating, contradicting, and/or challenging the traditional moral code on female sexual behavior.

On 28 November 2017, Manasseh Azure Awuni, a high-ranking, award-winning investigative journalist in Ghana published, "Manasseh's Folder: A Love Letter to Ebony." This open letter to Ebony Reigns, a 20-year-old, award-winning songstress, who was making headlines in Ghana for provocative behavior, was full of translated proverbs and offered general advice and a warning from Awuni to Reigns over what he described as her nudity during her musical performances. He asked her to focus on music and eschew nudity. In his letter, Awuni tried to establish his credibility (ethos) as a wise, elder male. His use of proverbs spoke to the virtues valued by his Ghanaian audience and culture. For instance, he writes "our elders have taught us that a wise child is not spoken to in plain words but in proverbs" (Awuni 2017). This quote is his understanding of a common proverb in Ghana that exists in some indigenous Ghanaian languages (e.g., Akan and Ewe) and suggests that if Reigns is wise, she will heed the traditional voices of the culture. More importantly, he completes that paragraph noting her similarities to the story of the "mad women of Kete-Krachi" (Awuni 2017). The mad women of Kete-Krachi, according to Awuni, references a young woman who spoke loudly or offensively in the town she lived, and she was so ambitious, she wore herself out and could only warn the next young

2 The term is believed to mean total opposite of a "good girl". In Jamaican Patois, it refers to a girl who does things that are deemed unacceptable by society, for instance, a highly promiscuous girl/female or a girl/female who makes a name for herself without conforming to what society sees as "right" for women. (https://jamaicanpatwah.com/term/Bad-Gyal/1796\# .Xvx3WfIaT2Q). 
women in hopes that they did not follow in the same steps (Awuni 2014 "Manasseh's Folder: Mensa Otabil"). Reigns, he explains, is very talented musically, but she will only be remembered for her nakedness and not her talent.

Awuni's letter gained traction on social media and was shared 11,900 times and received 514 comments on Facebook and myjoyonline.com. While a majority of the comments congratulated Awuni and affirmed his position in condemning Reigns's behavior and even added their own proverbs (e.g., "a housefly that refuses to heed advice will follow the corpse to the grave"); others disagreed with Awuni, especially over his description of nudity, but these responses spoke with a modern voice and avoided proverbs (e.g., "Call it seductive dressing but certainly not nudity ... otherwise it makes us hypocrites for I can't count the number of ladies I see every day dressed seductively"). Several voices chimed in on this example of normative female sexual behavior in contemporary Ghanaian society. Indeed, Awuni himself admits this in his letter when he says, "in this era of Facebook and WhatsApp, the wisest of our generation do not seem to be able to wrap their heads around the simplest of proverbs or the ancient wisdom of speech with which words were woven" (Awuni 2017 "Manasseh's Folder"). In other words, even though traditional rhetorical tools such as proverbs may have culturally encoded an ethos on female sexual behavior (among other things) in Ghanaian society, they may no longer be the main authority in social matters. More importantly, modern discourse tools, (e.g., Facebook, WhatsApp, and Twitter) may carry as much ethos, perhaps more, as proverbs in contemporary Ghanaian society.

In a socioculturally and religiously diversified country, there will be multiple voices on any subject matter including female sexual behavior. How is ethos, regarding the character and authority to speak persuasively on female sexual behavior, achieved in this sociocultural space? Who has the final say on matters of female sexual behavior in contemporary Ghanaian society?

While these two traditions of the classical period remain useful in the contemporary study of rhetoric, they appear "inadequate for postmodern epistemologies" (Johanna Schmertz 1999, p. 86). In postmodern thought, ethos is regarded as a discursive construction by both speaker and audience where neither speaker nor hearer has the final word because there is a rich tradition of conflicting interpretations.

In discussing African ethics, Kwame Gyekye (2010) describes ethics (in part) in a way similar to Wade Nobles (1972) definition of ethos:

The ethics of a society is embedded in the ideas and beliefs about what is right or wrong, what is good or bad character; it is also embedded in the conceptions of satisfactory social relations and attitudes held by the members of the society; it is embedded, furthermore, in the forms and patterns of behavior that are considered by members of the society to bring about social harmony and cooperative living. (p. 1)

In addition, the concept of ethos has been either directly or indirectly evoked by feminist rhetoricians particularly in discussing women's agency. For instance, Kathleen J. Ryan and her compatriots have called on (feminist) rhetoricians to rethink ethos and to define it in ecological terms, arguing that defining ethos in such terms "requires a consideration of an ecology of forces around ethos construction-not only social constructs like race and gender but also relations of power, and materiality (things and places)" (p. 1, 3). Similarly, Johanna Schmertz (1999) defines ethos (for feminism) as "neither manufactured nor fixed, neither tool nor character, but rather the stopping points which the subject (re)negotiates her own essence to call upon whatever agency that essence enables" (p. 86).

\section{Contextualizing Proverbs}

We analyzed selected proverbs that are common in Ghana regarding normative female sexual behavior to drive some of the discussion toward how discourses on female sexual ethos have been created in contemporary Ghanaian society. First, starting with the proverbs from Awuni's letter to Reigns and the comments that followed, we focus on proverbs that speak to normative female sexual behavior in Ghana, most notably Noah K. Dzobo's African Proverbs texts and Peggy Appiah, 
Kwame Anthony Appiah, and Ivor Agyeman-Duah's Bu Me Be: Proverbs of the Akans, which are both published and widely circulated collections of Ewe and Akan proverbs. Secondly, we examine the ways in which the general Ghanaian public responded to discourses surrounding Reigns through various social media platforms, which create an individual sexual identity that is not familiar to many contemporary Ghanaians as "culturally Ghanaian".

For us, proverbs provide a cultural opening to explore Ghanaian ethos. Of course, proverbs are typically defined as short, pithy sayings that express traditionally held truths or pieces of advice and are usually based on common sense or experience. Proverbs tend to be a source of dominant ideologies, because they are believed to reflect a people's philosophy, cultural, and ethical values. Proverbs have been studied widely across disciplines and across cultures; some examples include, Irish (Fred Norris Robinson 1945), English (Frank Percy Wilson 1994), Chinese (Lister 1974), and Yiddish (Beatrice Silverman-Weinreich 1981). Proverbs play an important role in many communities, especially those that are predominantly oral, serving both as a memory bank for preserving and as a vehicle for transmitting wisdom and knowledge. Consequently, proverbs are a powerful tool in representing, influencing or shaping the worldview of a group, often reflecting customs, practices, and prejudices of a group.

As already reviewed, we use Aristotle to establish an ethotic framework for contemporary Ghanaian social discourse but proceed to consider the ways that social media test and extend-and in some important ways subvert-the classical Aristotelian model, particularly when the speaker is a young Ghanaian woman. Some proverbs employed in Ghanaian popular discourse conform to the classical Aristotelian model, primarily when their speakers are culturally-situated as masculinist/misogynist and moralizing. Often proverbs can also have a subversive effect on masculinist authority when deployed by women, particularly by women in business and entertainment and when engaged in behaviors discountenanced by traditional masculinist authority. Hence, contemporary Ghanaian discourse inhabits a cultural-dialogic space "in between" the (conservative) traditional oral folkways and the (transgressive/progressive) "new media". It is, in sum, caught in transit between traditional and progressive cultural-discursive norms. In this regard, we may describe contemporary Ghanaian society as a liminal space where there is an obvious break from normative cultural patterns, and where new practices that question normative cultural practices have emerged but the old normative practices are not completely abandoned, (Victor Turner 1974; Joseph Jeyaraj 2004).

Here we consider ways that contemporary Ghanaian social media co-opts proverbial discourse within an agonistic or competitive mediated space that crosses gender, age, occupation, and class. We note that Ghanaian proverbs warrant a rhetorical/ethotic vocabulary of their own, independent of classical Aristotelian theory. While we see proverbs as a source of dominant/normative ideologies (including those on female sexual behavior), we also recognize social media as a platform for interactions among people of all ages, and it represents a social space where both dominant and emerging ideologies on female sexual behavior may be expressed, especially because the interactions on social media "are sometimes anonymous or pseudonymous" (Kozinets 2012, p. 39).

\section{Proverbs as Ideology on Female Sexual Behavior}

Proverbs provide one snapshot into contemporary Ghanaian society. For instance, Kofi Agyekum (2000, 2005, 2012) analyzes proverbs as an aspect of Akan oral literature through mass media in contemporary times, most notably in the lyrics of contemporary Ghanaian music, aphorisms, and marriage proverbs. Similarly, Yankah $(1986,1989,1999)$ discussed proverbs as part of the aesthetics of traditional communication in Ghana (1989) and as rhetoric in the context of the African judicial process (1986). Awuni's love letter to Reigns derives its authority from proverbs and other forms of rhetorical traditions, tales, and stories. Awuni references translated proverbs and attributes them to "the elders," who are believed to be custodians of Ghanaian cultural values. Indeed, Awuni's condemnation of Reigns's manner of dress (calling it "nudity") is based on what he describes as "what 
our elders have said." For instance, part of his advice to Reigns requests her to speak to an elder; he writes:

And anytime you want to repeat what you recently said about your nudity, kindly ask your father to tell you what our elders meant when they said,

"The disease that will kill a person first breaks sticks into their ears."

(Awuni 2017)

Following this, we identified other similar proverbs from Dzobo's work and from Appiah, Appiah, and Agyeman-Duah's collection that speak to ideologies on normative female sexual behavior that we articulate below. While we do not fully explore every meaning of each proverb, readers will be able to interpret them through their own cultural lens as well, which only enriches our discussion and our collective understanding of them. The following Ghanaian proverbs are well known and, we suspect, easily understood by a general audience: Proverbs a, d, f, h and k are from Dzobo (1975); Proverbs c, I, $\mathrm{j}$ and $\mathrm{g}$ are from Dzobo (2006) and Proverbs b and e are taken from Peggy Appiah, Anthony Appiah, and Ivor Agyeman-Duah (Appiah et al. 2007).

a. A woman does not speak with the voice of a man. This Ewe proverb explicitly puts a man and a woman in two mutually exclusive categories. In addition, it suggests a women's voice is not equal to a man's, even inferior.

$b$. When a woman buys a gun, it lies in a man's room. More than make an essentialist assumption about men and women, this Akan proverb places a limitation or a barrier on the abilities that women can have, their authority, and how ownership of material goods (especially those that are masculine by cultural or perhaps universal understanding) remains with the male and not the female.

c. All crows look alike but not all of them lay eggs. This proverb is used as advice, particularly to young men about how to choose their girlfriends or future wives. In essence, even though women look attractive or seem the same, their characters and personalities are not similar. In other words, not all women are suitable wife/mother material, which returns to a misogynistic ideal of women as only bearers of children and subservient to the male, who is the dominant figure in the household.

d. Human beings are not palm wine. You cannot exploit them by tasting them. This proverb admonishes people who toy with human emotions, specifically in relationships, betrayals, and exploitation of the opposite sex. It is usually used as advice for young people regarding how they should relate to others.

e. We marry a woman for her utterances (character) and not for her privates (sexual attractiveness, sex). This proverb emphasizes the importance of good character over lust and sexual attraction. This is commonly spoken to young men when they are considering choosing a wife, again which suggests he is the one choosing her and lesser so the reverse.

f. A girlfriend is not attended to like a farm. This Ewe proverb reflects on Ewe farmers who traditionally believe in paying close attention to and investing in one's farm in order to get a good yield. The proverb is normally used to caution men not to put too much care and money into their relationships with women because there is no guarantee of absolute faithfulness from women. This proverb, thus, may be argued to be an example of the misogynistic bent of Ewe culture in its views of women and their perceived promiscuity.

g. One beautiful girl cannot be married into two houses at the same time. This proverb is often used as advice given to a young woman who overestimates her beauty and usefulness in her relationships with men. This proverb also imposes some implied restrictions about relationship choices on the female, while expanding them for the male.

$h$. It is difficult to marry the daughter of a mother-in-law who receives money from two suitors. To paraphrase, it is difficult to do business with a double dealer or dishonest person. This proverb chooses a 
woman, a mother-in-law, to illustrate duplicity in a society where mothers never receive bride price or dowry; whether in patriarchal or matriarchal cultures, moneys and gifts related to marriage are paid to fathers and uncles in Ghanaian society. This proverb implies that mothers-in-law are mostly crooked people.

i. Walking on the pavement is better than walking in the middle of the street. This proverb exhorts one to avoid being an attention seeker or being forward and instead to value modesty, silence, and, to a lesser degree, submission. Thus, being modest, not being in the limelight, is a desirable value in traditional Ghanaian society.

j. The fool cares for his beard, the wise man, his character. This proverb is similar to proverb $\mathrm{f}$ in intent. The common understanding of traditional Ghanaian ethos is strongly against those who are looks-obsessed and vain. From its perspective, good character bests good looks, physique or fashionable clothes.

k. You don't dissect the stomach of a crocodile in public. This Ewe proverb has an equivalent in Akan that says that you do not wash your dirty linen in public. This proverb admonishes one not to discuss or showcase confidential or private matters in public such as sex or disagreements. The proverb places a premium on tactfulness and privacy in matters that the society considers sensitive or taboo.

Through these proverbs, we agree with some Ghanaian scholars (e.g., Diabah and Amfo 2015), who have described Ghanaian traditional culture as patriarchal, male-biased, and enforcing gendered roles and spaces, where rigid, essentialist roles with regard to who/what men and women are or can be, and what women and men can/cannot or should/should not do exist. These concepts are illustrated in proverbs a-c above. Again, there appears to exist a certain expected appropriate sexual behavior for young people and Etego-Amengor (2014, p. 257) has argued that the concept of Ghanaian chastity "is about the virtuous woman; the woman who exudes the traditional concept of decorum, modesty, self-service and dignity in all spheres of life". This view is similar to the concepts in proverbs d-i which highlight the expected sexual behavior and emphasize moral values/character (of women), rather than physical beauty/sexual attractiveness. Consequently, if a woman emphasized her sexual attributes in any perceivable way, she might typically be described as immoral (violating an ethos of sexual behavior).

Thus, the features of ethos/philosophy on sexual behavior as demonstrated above show these Ghanaian proverbs may be similar to John Bender and David E. Wellbery's definition of classical rhetoric as "an art of positionality in address. Audience are characterized by status, age, temperament, education, and so forth. Speakers are impersonators who adapt themselves to occasions in order to gain and maintain position", and that "rhetorical speech marks and is marked by social hierarchy" (Bender and Wellbery 1990, p. 7). In this regard, we describe proverbial ethos on female sexuality as projecting age, male dominance, and male authority as normative. To be specific, men are the definers and women are largely the defined; that men create power (over women) through the use of language to assert power. Perhaps, this explains why Awuni, a male with authority (established/accomplished, award-winning journalist) grounds his authority in what the elders (who are typically men) have said in proverbs to advise Reigns, a young, powerless female (school drop-out/songstress) and even condemn her sexual presentation (scanty mode of dressing). Recall that both Awuni and some of his supporters who applauded his letter to Ebony, used proverbs, especially in condemning Reigns. Certainly, we conclude that proverbs are a source of dominant ideologies on ethos in contemporary Ghanaian society.

\section{Ethos through Ghanaian Understanding and Beyond}

According to Kenneth Burke (1966), in Language as Symbolic Action, language may be used to "defeat reality" (p. 45). In other words, a speaker may use language to deflect their audience's attention toward or away from certain realities or ideologies. In what follows, we describe how Reigns, the young, female drop-out who is not traditionally regarded as an authority on normative female 
sexual behavior uses language (discursive practice) in an attempt to defeat the reality of traditional Ghanaian ethos on female sexual behavior. We examine some social media discourses around her and the controversy she generated in order to infer how she created an identity and a voice that challenged normative Ghanaian ethos on female sexuality.

We begin with some discussion of her music. The lyrics of her songs became a flashpoint that openly critiqued Ghanaian traditions and cultural norms. For example, the lyrics of her song "Sponsor" exposed the justification and even glorification of the exploitation by young women of older men (for material gain) on one hand, and of young men (for sexual pleasure) on the other hand as shown in the excerpt below:

See I'av got myself a sponsor

Anthing me i ask edey buy buy

Even though he is older

Another one who is younger

When I ask for something eday cry cry

Mese papa yi a m'nya no yi dec Jmame bibiaa [the older man provides my material needs]

cnso edru anadwo a wobchwe na aka me nkoaa [but I am lonely at night]

cdaa כbeba me nkycn me so ne mu asem a Jka ne se [when I touch him on the day he visits me he retorts]

Cool it for me slow down .....

Me sisi ye mi ya [I have waist pains]

Oh Lord have mercy mercy mercy

These broke guys have lot of energy

Inna me down town hot just like oven

But when the morning comes me no have nothing

A boyfriend who can't buy you food when you are hungry ${ }^{3}$

(https://www.musixmatch.com/lyrics/Ebony/Sponsor)

The lyrics in this song violate the spirit of proverbs $d$ and $g$ above. Contrary to traditional thinking, the song questions why a woman cannot keep two men at the same time, especially given the fact many men do keep two women at a time. Further, the lyrics of another of her songs, "Date Ur Fada [your father]," challenge the traditional Ghanaian ethos that permits promiscuity among men but not women by threatening (perhaps, proposing) to engage in an incestuous relationship (that is, date the father of her promiscuous lover), a traditional taboo in Ghana. Below are excerpts from Reigns's song "Date Ur Fada":

If you break my heart i go date ur fada

Bony pon dis

Danny beatz

The 90's badgyal trend

See i heard them say, heard them say

Boy you a player

You dey score like Messi, play like Kaka

Dribble like Wakaso

You dey like Barcelona, Real Madrid

Arsenal, Man U, Chelsea

3 Translations in brackets provided by the authors, who are L1 and L2 speakers of Akan, the main language of the music. 
I go give you my heart, give you body

Do anything for you

Sacrifice my life to be your wife

I'm gonna be there for you

But if you break my heart

I go date ur fada

You gonna be my son

You go call me your mother

Bakasi you know sey I get am o

Bobbie stand you know sey I own am o

And no style dey wey I no sabi do am o

Me I no like Versace

And I no like Designer

Me I no like Ferrari

And I no like Bugatti

But if you break my heart

I go date ur fada

You gonna be my son

You go call me your mother

(https://www.musixmatch.com/lyrics/Ebony/Date-Ur-Fada)

Before her death in February 2018, particularly in the months of November and December 2017, Reigns came under intense criticism in Ghana over both her mode of dressing and her lyrics. Both were perceived to be violations of normative female sexual behavior in Ghana (see proverbs $\mathrm{i}-\mathrm{k}$ above). The criticisms came in various forms, ranging from friendly advice to downright insults and condemnation through several avenues including social media posts, open letters in online newspapers, and even to radio call-in programs. These criticisms came from people from all walks of life and across different sections of Ghanaian society, including men, women, gospel musicians, and journalists. These criticisms received interesting reactions from other members of the Ghanaian public. We present a few selections of some of these criticisms and reactions as they occurred in real time on social media and other media platforms, in order to infer what contemporary Ghanaian ethos on appropriate female sexual behavior appears to be.

On 7 August 2017, a female Afrobeat artiste, Feli Nuna, was reported on myjoyonline.com to have asserted that the lyrics of Reigns's song "Sponsor" were influencing young people negatively (MyjoyOnline.com 2018). Later in November 2017, Reigns was reported in the Ghanaian media to have dressed in such a way as to reveal portions of her private parts during a high-profile entertainment event. As soon as the news broke, the president of the Musicians Association of Ghana (MUSIGA), Bice Osei Kuffour (aka, Obour), gave a TV interview on Joy TV condemning Reigns's manner of dressing, describing it as "bad" and not conforming to the moral values of Ghana (myjoyonline.com, proverb b). Like the Awuni letter, many people on social media supported Obour's remarks and clearly pointed to societal expectations of conformity to a Ghanaian ethos by young women. This response contrasts a similar incident in which a young Ghanaian male musician, Wisa Greid, exposed his genitals during a concert. While many people saw Greid's behavior as inappropriate and he was arrested by the police, the general reaction of the public was that his behavior was a mere youthful exuberance (notably male). More importantly, his reputation was unscathed, perhaps even bolstered. In reaction to Obour's condemning comments, which were carried across social media, Reigns responded to the MUSIGA president in a Facebook post on November 29 2017: 
Ebony reigns dressing is very bad and is not our culture, but 'chopping' of[f] musicians' money is very good and i think that is our culture.some gh musicians are dying of hunger and what is ur union doing about that mr president? do you really care? \#hustle. (Reigns 2017)

Shortly thereafter, Reigns's post on Facebook which was also published peacefmonline.com (Peacefmonline.com 2017) on 30 November 2017, received over 4000 likes, 43 shares, and 223 comments. In countering Obour, the MUSIGA president, Reigns "spoke with the voice of a man," (proverb a). Traditional Ghanaian ethos does not allow younger people, in general, and particularly women and most especially younger women, to contradict or talk back to an older man or to an authoritative male figure. This is seen as disrespectful and, thus, a violation of traditional behavior codes. As expected, some "senior" musicians went on record to advise the songstress to apologize to the president of their association. For more context, Obour once released an award-winning song (Konkontibaa, tadpole) whose lyrics promoted the early sexualization of young girls by men. However, he was never expected to apologize to Ghanaian society, not even by female activists/feminists. In this testy exchange, however, many of Reigns's online followers referenced his song and questioned Obour's authority to judge her, calling him a hypocrite. Another fan of Reigns questioned Obour's credibility in these matters based on his own manner of dressing in the following Facebook post:

- $\quad$ Yayra Koku (Yayra 2017). Nov 292017 @11:41 a.m.:

- "Obour hair is Rasta. Is Rasta our culture? So many fools in this country...

- Does he understand BRANDING? Ebony pls next time wear only panties..."

It was in the midst of this controversy that Awuni wrote the open love letter to advise and condemn Reigns at the same time. It is important to note that while Awuni condemned Reigns's manner of dressing and called it nudity and advised her to desist from it, he praised her talent and voice and urged her to concentrate on developing those aspects. In this regard, Awuni was speaking in the voice of the elders, that is, that Ebony, as a young woman, should express beauty in character and not sexual attractiveness. Still in the month of November 2017, an award-winning UK-based gospel musician, Sony Badu, endorsed Reigns's talent and tagged her critics as hypocrites in an online post. His post attracted 235 likes on Adomonline.com (Adomonline.com 2017) and 23 comments on ghanaweb.com (Ghana 2017): two popular social sites in Ghana. As usual, while some comments were affirming both Sony Badu and Reigns, others insulted both of them or questioned Sony Badu's Christian/moral values. Finally, in an article on 8 December 2017, BenjaminAkyena Brantuo, a broadcast journalist, described the Ebony controversy in Ghana as hypocritical/contradictory on the part of the many who condemn her behavior/morals. As he points out, "When the respectable people of our society want to relax with good music, laced with sexual lyrics, performed by a beautiful actress, scantily dressed, guess where they go-Ebony's shows!" (Akyena-Brantuo 2017). Moreover, Reigns received frequent invitations to perform at high-profile events and he concludes that "While it is convenient to disrespect and or condemn Ebony for her dressing, apparently, she does it for our sake" (Akyena-Brantuo 2017). The more pointed element to Benjamin's article exposes the hypocrisy in Ghanaian society. He details as more deserving of attention, the "nepotism and cronyism," the failures of the educational system, and various structures of corruption such as illegal mining and getting unqualified relatives into "grade A schools through the back door" (Akyena-Brantuo 2017). While he exposes these realities, he concludes with a (proverbial) Bible verse (Matthew 7.5): "You hypocrite, first take the plank out of your own eye, and then you will see clearly to remove the speck from your brother's eye."

It is obvious from the above discussion that traditional Ghanaian ethos on female sexual behavior is being challenged and re-fashioned in contemporary Ghana. While some online community members viewed Reigns's use of her sexuality negatively, others wrote that Reigns was young and ignorant. Others warned her of dire future consequences if she did not desist from her behavior. However, Reigns's supporters used many Christian references in their comments and called Reigns's critics hypocrites. They also argued that her detractors were guilty of doing worse things in secret and should 
reflect on their own double standards. These exchanges suggest a powerful and meaningful evolution of Ghanaian culture and its redress and reconsideration of traditional thinking.

\section{Conclusions: Ethos as Discursive Construction in Contemporary Ghana}

The evolution of a current Ghanaian ethos on female sexual behavior involves heteroglossic elements. Mikhail M. Bakhtin (1992, On Dialogism and Heteroglossia) defines heteroglossia as a form of verbal communication whose importance is seen in the fact that "it represents the co-existence of socio-ideological contradictions between the present and the past, between different socio-ideological groups" (p. 291). Applying this understanding to the social and online interactions and proverbs concerning female sexuality, we see the differing and emotive voices and viewpoints making themselves heard. Some of these voices represent dominant traditional, patriarchal normative ideologies (i.e., what the elders have said and the proverbs that have been passed down). Others, mostly young and liberal, subvert the dominant discourses of Ghanaian ethos on female sexual behavior in their support of Reigns's behavior. Indeed, Reigns projects her transgressive voice not only through her linguistic behavior (lyrics and responses to criticism) but also through her manner of dressing and her general way of life. While contemporary Ghanaian ethos is slowly evolving through these dialogic views in society, the latter voice is described by the former as "courting the rage of overzealous liberals and self-proclaimed feminists" (Awuni 2017).

From a feminist point of view, Ghanaian social media and, by extension, most of Ghanaian society, was reacting negatively to Reigns because of her perceived transgressions of Ghanaian traditional, cultural, and Christian moral codes concerning appropriate sexual behaviors for females (proverbs $\mathrm{b}, \mathrm{c}, \mathrm{f}, \mathrm{j}, \mathrm{k}$, and $\mathrm{l}$ ). Most importantly, these reactions occurred because she was a young female. Ghanaian traditional culture is patriarchal and directs Ghanaians into gendered roles and spaces. With modernization, education, and the assumption of authority, female power has grown exponentially in Ghana. Yet, it is still hard for many to accept public expressions of female sexuality and authority. In other words, traditional ideologies of female sexuality as revealed in proverbs and explained by Rosemary Etego-Amengor remain the dominant space. Nevertheless, there are emerging spaces, like that of Reigns. However, such spaces are viewed by many as unacceptable because they are created by young females who are not regarded traditionally as having authority. Indeed, Reigns fought for her differing/untraditional voice or stance in order to be heard. In other words, Reigns challenged and questioned the dominant voice on female sexuality in order to create autonomy for a young female voice. Further, Reigns's use of her body and voice is not only about forming a transgressive identity but also empowering other minority voices (e.g., young females) in a male-dominated culture. According to Bender and Wellbery (1990), what is happening in contemporary Ghanaian society is a common feature of many philosophical systems:

the cultural hegemony of [classical] rhetoric as a practice of discourse... is grounded in the social structures of the premodern world. Conceived in its broadest terms then, the demise of rhetoric coincides with that long and arduous historical process that is often termed modernization: the replacement of a symbolic-religious organization of social and cultural life by rationalized forms, the gradual shift from a stratificational differentiation of society to one that operates along functional axes. (p. 7)

The public's responses to Reigns represents a dialogism that is a part of the Ghanaian ethos today, as mentioned earlier. Other examples of dialogism in a similar vein involved an earlier incident in 2014 that occurred between an internationally known Ghanaian preacher and a young Ghanaian actress. The popular evangelical preacher Archbishop Duncan-Williams, in a sermon, declared that without marriage, a woman's achievements and contributions to society were useless. He further claimed that the ratio of women to men in the world was 7:1, and thus it was a privilege for a woman to find a man to marry her. He further admonished young women not to misbehave so that men would want to 
marry them. This sermon reinforced the ideas of female submission and dependency on men and the importance of good character for females (proverbs $a, b$, and i).

An unmarried young actress, Ms. Lydia Forson, countered the archbishop's message by writing a sarcastic letter proposing marriage to the already married Archbishop on several news forums in hopes, as she stated, of getting married and having relevance in life. Her letter forced the Archbishop to deny that he was a chauvinist and to state that he did not mean to offend or disrespect Ghanaian women in his sermon (Graphic.com.gh 2014) In this incident, Ms. Forson 'spoke with the voice of a man' (proverb a).

Normally, on the one hand, a man of the Archbishop's standing in Ghana would not be expected to respond to a young woman's rebuke or backtrack on his statements because a young woman was displeased by them. On the other hand, Ms. Forson, a young woman, would not be expected to push back so publicly against a male preacher of assumed high moral standing. This issue elicited hundreds of responses from the Ghanaian public with some supporting Ms. Forson and others, the Archbishop.

A more recent illustration of dialogism in contemporary Ghanaian society occurred in 2018 when a social media influencer and actress, Moesha Boduong, caused a stir in Ghana by telling CNN anchor, Christane Amanpour, that most Ghanaian young women have sex with older/rich men in order to make ends meet (myjoyonline.com). Once again, on the one hand, she was condemned by a huge section of Ghanaians including government officials and women's organizations, and was forced to publicly apologize to the nation for her 'disgraceful comments' which violated Ghanaian traditional ethos on female sexual behavior, as encoded in proverbs $i, j$, and $k$. With her comments, she had "washed her dirty linen in public". On the other hand, there was a huge social media support for Ms. Boduong, where it was argued that there was nothing wrong with her views. Thus, the nature of dialogism in Ghanaian society may be best captured by the following quotation from Bakhtin, (Speech Genres, Bakhtin 1984): “There is neither a first nor a last word and there are no limits to the dialogic context" (p. 170). In contemporary Ghanaian society, patriarchal, misogynist norms, traditional and religious philosophies regarding female sexuality no longer (singularly) define the sexual behavior of many young women. Their actions and candidness (which violate traditional rules discouraging explicitly sexual language, proverb 1) and their unashamed admissions concerning their use of their sexualities clearly show that young women like Reigns are not afraid to cross moral/taboo lines in traditional/social narratives (violations of proverbs $f, h, j$, and $k$ ). In fact, many Ghanaian women are challenging the proverbial ethos that seeks to reinforce normative notions of women's subservience and inferiority to men (proverbs a-c). These women employ intellectual, rather than the sexual pursuits which Reigns alludes to in her lyrics. Even though these two groups of women work on opposing sides, their actions contribute toward changing the traditional Ghanaian ethos. Thus, they generate new forms that respond to a climate mediated by technological and gender-sensitive influences.

The public condemnation of Reigns' desire to celebrate her sexuality in public and on social media seems contradictory when one considers Ghanaian traditional expectations that women satisfy their husbands sexually any time they demand it. Some possible influences that have also challenged the dominant Ghanaian ethos on female sexuality and emboldened young women like Reigns to be sexually daring, may be found on social media, entertainment, and film industries. Outside of Ghana, American reality stars such as Kim Kardashian and hip hop stars such as Nikki Minaj and Cardi B (whose sexiness contribute significantly to their success), push some young Ghanaian female artistes into modeling these sexually explicit behaviors. The sexualized images of the American stars send messages to young women that to be seen as beautiful, attention-worthy, and successful, they must utilize their sexuality. In this regard, the use of proverbs, which have been described as enthymemes in Aristotelian rhetoric, to encode these cultural norms suggests that the Ghanaian culture/society is not inherently authoritarian but open to dialogism. Thus, the study of proverbs may be important in creating a dialogical theory that incorporates voices from contexts that are less studied or represented in the literature. 
Contemporary Ghanaian ethos on female sexual behavior reveals itself through heteroglossia by multiple discursive practices, including traditional proverbs and modern communicative avenues (e.g., social media). Social media has given (young) women like Reigns massive online platforms. With these, they not only challenge dominant ideologies on female sexuality in contemporary Ghanaian society, but also showcase their sexualities and lifestyles as alternatives to the dominant ones. These underrepresented voices embody the polyphony that is shaping new forms of ethos through dress, character, address, and morality in Ghana. The heteroglossic elements of the traditional, the transgressive, gender and class dimensions, all contribute to evolving ethotic forms co-existing in an uneasy mix in contemporary Ghanaian society. As has been observed by Chris Abotchie (2006) and Gladys N. Ansah (2017), theGhanaian society seems to be still emerging (but not weaned) from traditional beliefs and practices in many aspects of life.

From the above discussion, it is evident that this paper contributes to feminist rhetorical scholarship by including the voices of Reigns and by implication, other (young) women into mainstream (traditional) Ghanaian discourse formerly dominated by male voices. The paper demonstrates how young females (powerless by Ghanaian cultural precepts) exert power in society by exhibiting feminist attributes of daring, crossing traditional gender lines and challenging the submissive and dependent roles assigned by their society/culture. The paper illustrates how Ebony Reigns influences a significant segment of young Ghanaians by using her sexuality, behavior, and words as persuasive tools to affect a paradigm shift and contribute to the shaping of a contemporary Ghanaian ethos on female sexuality.

This paper's focus also expands our awareness of female voices and shows the intersections of Ghanaian feminist rhetoric with tradition, culture, and social change. This is critical to a deeper understanding of Ghanaian culture, both past and present.

In addition, this work treats proverbs and ethos from an angle that is different from what past researchers have done with the subject. Our study goes beyond the description of proverbs and their portrayal of women to show their (proverbs) role in not only shaping traditional Ghanaian ethos but also how gender disrupts proverbial influence and creates new ethos forms. This study is also significant in its presentation of a female rhetor as a subject and as a power player in contemporary Ghanaian ethos formation. Unlike other studies in this area of Ghanaian proverbs and ethos, this study employs computer-mediated responses in real time from numerous responders on social media platforms to gauge public reactions towards the female subject/rhetor-Reigns. Thus, the study presents the continuously evolving shift in Ghanaian ethos, setting it apart from other studies in this area.

Finally, the findings of this study contribute to the contemporary debate about cultural identity as well as critical social discourse, and the role rhetorical concepts play in advancing such debate.

Author Contributions: Both authors contributed in equal measure with regard to the conceptualization, writing, reviewing, and all other aspects of the article. All authors have read and agreed to the published version of the manuscript.

Funding: This research received no external funding.

Acknowledgments: We are grateful to the co-editors of this Special Issue, Craig A. Meyer and James S. Baumlin, for their support and inviting us to contribute to this volume.

Conflicts of Interest: The authors declare no conflict of interest.

\section{References}

Abotchie, Chris. 2006. Has the position of the chief become anachronistic in contemporary Ghanaian politics. In Chieftaincy in Ghana: Culture, Governance and Development 1. Edited by Irene K. Odotei and Albert K. Awedoba. Accra: Sub-Saharan Publishers, pp. 169-81.

Adomonline.com. 2017. Available online: https:/www.adomonline.com/ghana-news/video-sonnie-baduendorses-ebonys-talent-tags-critics-hypocrites/ (accessed on 12 December 2017).

Agyekum, Kofi. 2000. Aspects of akan oral literature in the media. Research Review 16: 1-18.

Agyekum, Kofi. 2005. An Akan oral artist-the use of proverbs in the lyrics of Kwabena Konadu. Institute of African Studies Research Review 21: 1-17. [CrossRef] 
Agyekum, Kofi. 2012. Akan proverbs and aphorisms about marriage. Institute of African Studies Research Review 27: 1-24.

Akyena-Brantuo, Benjamin. 2017. “Ebony Reigns is a Saint!" MyJoyOnline. Available online: https://www. myjoyonline.com/opinion/ebony-reigns-is-a-saint/ (accessed on 8 January 2018).

Ansah, Gladys Nyarko. 2017. Cultural conceptualisations of DEMOCRACY and political discourse practices in Ghana. In Advances in Cultural Linguistics. Edited by Sharifian Farzad. Singapore: Springer, pp. 369-87.

Appiah, Peggy, Anthony Appiah, and Ivor Agyeman-Duah. 2007. Bu me be: Proverbs of the Akans. Banbury, UK: Ayebia Clarke.

Awuni, Manasseh Azure. 2014. Mannasseh's Folder: Mensa Otabil and the Mad Women of Kete-Krachi. Available online: https://www.todaygh.com/manassehs-folder-mensa-otabil-mad-women-kete-krachi/ (accessed on 10 November 2019).

Awuni, Manasseh Azure. 2017. Mannasseh's Folder: A Love Letter to Ebony. Available online: http://www. manassehazure.com/2017/11/manassehs-folder-love-letter-ebony/ (accessed on 8 January 2018).

Bakhtin, Mikhail Mikhaĭlovich. 1984. Speech Genres and other Late Essays. Edited by Caryl Em-erson. Minneapolis: University of Minnesota Press.

Bakhtin, Mikhail Mikhaullovich. 1992. The Dialogic Imagination: Four Essays. Translated by C. Emerson, and M. Holquist. Austin: University of Texas Press, vol. 1.

Baumlin, James S., and Craig A. Meyer. 2018. Positioning Ethos in/for the Twenty-First Century. Humanities 7: 78. [CrossRef]

Bender, John, and David E. Wellbery. 1990. Rhetoricality: On the Modernist Return of Rhetoric. In The Ends of Rhetoric: History, Theory, Practice. Edited by John Bender and David Wellbery. Stanford: Stanford University Press, pp. 3-39.

Burke, Kenneth. 1966. Language as Symbolic Action. Berkeley: University of California.

Diabah, Grace, and Nana Aba Appiah Amfo. 2015. Caring supporters or daring usurpers? Representation of women in Akan proverbs. Discourse E Society 26: 3-28.

Dzobo, Noah K. 1975. African Proverbs. The Moral Value of Ewe Proverbs. Guide to Conduct; Accra: Bureau of Ghana Languages, vol. II.

Dzobo, Noah K. 2006. African Proverbs. A Guide to Conduct. Vol. III. The Moral Value of Ewe Proverbs. Accra: Woeli Publishing Services.

Etego-Amengor, Rosemary. 2014. Critiquing African Traditional Philosophy of Chastity. Studies in World Christianity and Interreligious Relations 48: 251-72.

Ghana web.com. 2017. Available online: https://www.ghanaweb.com/GhanaHomePage/entertainment/SonnieBadu-endorses-Ebony-s-talent-and-tags-her-critics-as-hypocrites-609249 (accessed on 13 December 2017).

Graphic.com.gh. 2014. Duncan-Williams Rejects Lydia Forson's Proposal. Available online: graphic.com.gh/news/ general-news/duncan-williams-rejects-lydia-forson-s-proposal.html (accessed on 10 June 2018).

Gyekye, Kwame. 2010. African ethics. In Stanford Encyclopedia of Philosophy. Austin: The University of Texas at Austin.

Jeyaraj, Joseph. 2004. Liminality and othering: The issue of rhetorical authority in technical discourse. Journal of Business and Technical Communication 18: 9-38. [CrossRef]

Kennedy, George A. 1991. Aristotle on Rhetoric: A Theory of Civic Discourse. New York: Oxford University Press.

Kozinets, Robert V. 2012. Marketing netnography: Prom/ot (ulgat) ing a new research method. Methodological Innovations Online 7: 37-45. [CrossRef]

LeFevre, Karen Burke. 1987. Invention as a Social Act. Carbondale: Southern Illinois University Press.

Lister, Alfr. 1974. Chinese proverbs and their lessons. China Review 3: 134-35.

MyjoyOnline.com. 2018. I'm Sorry-Moesha Boduong Apologises to Ghanaians after CNN Backlash. Available online: https://www.myjoyonline.com/entertainment/2018/april-13th/imsorry-moesha-boduong-apologisesghanaians-after-cnn-backlash.php (accessed on 5 July 2018).

Nobles, Wade W. 1972. African philosophy: Foundations for Black psychology. A turbulent Voyage. Readings in African American Studies, 280-92.

Peacefmonline.com. 2017. Ebony Replies Obour: 'If My Dressing is Not Good, is Chopping Musicians' Money Good?'. Available online: http://www.peacefmonline.com/pages/showbiz/news/201711/336916.php (accessed on 9 January 2018). 
Rapp, Christof, and Edward N. Zalta. 2010. The Stanford Encyclopedia of Philosophy. Austin: The University of Texas at Austin.

Reigns, Ebony. 2017. Ebony Reigns Dressing is Very Bad. Available online: https://www.facebook.com/ebonygh/ posts/\%20842663095906236?comment_id=842844272554785\&comment_tracking=\%25257B $\% 252522 \operatorname{tn} \%$ $252522 \% 25253 \mathrm{~A} \% 252522 \mathrm{R} 9 \% 252522 \% 25257 \mathrm{D}$ (accessed on 8 January 2018).

Robinson, Fred Norris. 1945. Irish proverbs and Irish national character. Modern Philology 43: 1-10. [CrossRef]

Schmertz, Johanna. 1999. Constructing essences: Ethos and the postmodern subject of feminism. Rhetoric Review 18: 82-91. [CrossRef]

Silverman-Weinreich, Beatrice. 1981. Towards a structural analysis of Yiddish proverbs. In The Wisdom of Many: Essays on the Proverb. Edited by Wolfgang Mieder and Alan Dundes. Wisconsin: University of Wisconsin, pp. 65-85.

Turner, Victor. 1974. Social dramas and ritual metaphors. In Dramas, Fields, and Metaphors: Symbolic Action in Human Society. Edited by Victor Turner. Ithaca, NY, USA: Cornell University, pp. 23-59.

Wilson, Frank Percy. 1994. The proverbial wisdom of Shakespeare. In The Wisdom of Many: Essays on the Proverb. Edited by Mieder Wolfgang and Alan Dundes. Wisconsin: Wisconsin University Press, pp. 174-89.

Yankah, Kwesi. 1986. Proverb rhetoric and African judicial processes: The untold story. Journal of American Folklore 99: 280-303. [CrossRef]

Yankah, Kwesi. 1989. Proverbs: The aesthetics of traditional communication. Research in African Literatures 20: 325-46.

Yankah, Kwesi. 1999. Proverb. Journal of linguistic Anthropology 9: 205-207. [CrossRef]

Yayra, Koku. 2017. "Comment on Ebony Reigns Dressing is very Bad ..." Facebook. Available online: www.facebook.com/ebonygh/posts/842663095906236?comment_id=842844272554785\&comment_ tracking=\%25257B $\% 252522 \mathrm{tn} \% 252522 \% 25253 \mathrm{~A} \% 252522 \mathrm{R} 9 \% 252522 \% 25257$ (accessed on 29 November 2017).

(C) 2020 by the authors. Licensee MDPI, Basel, Switzerland. This article is an open access article distributed under the terms and conditions of the Creative Commons Attribution (CC BY) license (http://creativecommons.org/licenses/by/4.0/). 